\title{
Flexibility vs. Rigidity: does Spain have the worst of both worlds?
}

\author{
Gilles Saint-Paul ${ }^{\infty}$ \\ Universitat Pompeu Fabra, CEPR, and IZA \\ March 17, 2000
}

\begin{abstract}
A bstract
In this paper we study the structure of labor market $\ddagger$ ows in Spain and compare them with France and the US. We characterize a number of empirical regularities and stylized facts. One striking result is that the job ..nding rate is slightly higher than in France, while the jon loss rate is much higher, putting Spain half-way between France and the US. This suggests that while Spain has borne the full cost of its labor market reforms in terms of job precarity, the bene..ts in terms of job creation have been quite modest. We hypothesize that this has been due to the reform's credibility being imperfect, which leads to expectation of reversal.

J EL: J 20, J 21, J 23, J 41, J 42,J 63, E 24

K eywords: Unemployment, Labor market łows, J ob ..nding, J ob loss, Flexibility, Temporary contracts, labor market reform, Unemployment duration, Unemployment recurrence, On the job search, Labor force composition
\end{abstract}

\footnotetext{
${ }^{\natural}$ thank A Ifonso R osolia for research assistance, as well as the Direction de la Prévision, ministère des ..nances, Paris, and fundacion BBV for ..nancial support.
} 


\section{Introduction}

A mong European countries characterized by rigid labor markets, Spain is notable for a certain number of speci..c characteristics. First, over the last 25 years its unemployment rate has virtually been the highest in Europe, oscillating between $15 \%$ and an appalling $25 \%$. Second, at face value it has one of the most rigid set of institutions, in particular concerning the structure of collective bargaining and employment protection legislation. ${ }^{1}$ It dixers from other European countries, however, in having implemented a farreaching liberalization of employment protection regulation. This liberalization occurred in 1984, when, rather than reducing dismissal costs across the board, which would have been politically unfeasible, the government eased the use of temporary labor contracts ${ }^{2}$. Following this reform an employment boom occurred, where temporary contracts accounted for almost $95 \%$ of new hires, and quickly reached a $30 \%$ employment share. However, in the subsequent recession of the mid-nineties, employment dropped very quickly as ..rms could easily get rid of their temporary workers. In the end, there is no strong evidence that such a reform reduced unemployment.

This does not mean, however, that the reform has not axected the structure of the labor market. It is reasonable to speculate that it has increased labor turnover, and even absent a positive exect on the aggregate stock of unemployment, this may be considered as bene..cial as the duration of unemployment is reduced.

In order to learn more about the exect of the reform, or more generally the speci...cs of the Spanish labor market compared to other European countries, this paper compares unemployment levels and transition rates by education, sex, and age groups for Spain, France and the U.S. We take France as a similar

\footnotetext{
${ }^{1}$ See Blanchard et al. (1995).

${ }^{2}$ See Segura et al. (1991), B entolila and Saint-P aul (1992), B entolila and D olado (1994), $J$ imeno and Toharia (1991) for an account of this episode.
} 
European-style country, but where reform has been much more timid, while the U.S. is the benchmark case of a competitive labor market.

A previous study by Cohen et al. (1997) has shown quite similar unemployment rates by cells, thus ascribing a great deal of the unemployment dixerential between France and the US to a composition exect due to the higher proportion of americans who go to college. They have also shown that despite these similar unemployment rates, the labor market in France functioned quite dixerently from the US one, since the exit from unemployment was much lower in France, and consequently the duration of unemployment was much longer. The similar unemployment rates came from the fact that the job loss rate was also much smaller in France than in the US, presumably because of more stringent job protection legislation and/ or a cultural aversion to dismissals.

We look at the same variables as Cohen et al, using a decomposition of the population into three age, two sex, and four education groups. We also systematically report the numbers they ..nd in order to ease the comparison. Finally, we look at some deeper characteristics of the Spanish labor market such as duration dependence and unemployment recurrence. ${ }^{3}$

The main lessons of the paper are as follows.

First, and most importantly, the large unemployment dixerential between France and Spain is mostly explained by a much larger job loss rate in Spain compared to France rather than a smaller job ..nding rate. Indeed, the job ..nding rate is also higher in Spain, but only marginally, while the job loss rate is substantially higher, putting Spain half-way between France and the U.S.

This suggests that Spain has the "worst of both worlds", namely a job creation rate similar to that of a "rigid economy" ' and a job destruction rate

\footnotetext{
${ }^{3}$ Our ..ndings are roughly in accordance with other Spanish studies on $¥$ ows, such as Garcia Perez (1997) and Garcia-Fontes and Hopenhayn (1993).
} 
comparable to that of a $\ddagger$ exible one. Therefore, while employers do take advantage of the margin of fexibility allowed by temporary contracts at the time of ...ring, they do not consider that their availability reduces labor costs signi..cantly. Following an argument developed by B ertola and Ichino (1996), one may speculate that this is due to the reform lacking credibility. That is, ..rms have been unsure about whether the reform would not be overturned, with some discretionary tightening of the conditions under which temporary contracts may be used. Consequently, they have been cautious when hiring people, fearing that ..ring restrictions might be increased between now and the time they might want to get rid of their workers. While lower ..ring costs increase dismissals right away, it is the expectation of lower ..ring costs in the future which increases hirings. The impact of the reduction in ..ring costs on hirings is lower, the less con..dent are ..rms that the reform won't be overturned. Hence, for a reduction in employment protection to increase hirings, it is fundamental for the reform to be credible.

Second, the young suxer more from unemployment relative to the middleaged in both Spain and France compared to the U.S. (where it is also true that they suxer more). It is often believed that this is due to rigidities such as the minimum wage which make it too costly for employers to hire youngsters. Our data on ‡ows suggest that this interpretation is wrong. In fact, in all three countries a young unemployed person is more likely to ..nd a job than a middle aged. Their greater unemployment rate is explained by a greater in $\ddagger$ ow into unemployment, not a smaller out $\ddagger$ ow. We interpret that ..nding as evidence that in France and Spain, the bulk of łexibility has been concentrated on young people.

Third, we ..nd evidence of path dependence in labor market transitions. This means that an unemployed worker is more likely to be in unemployment a year from now than his monthly exit rate would suggest. This feature may be due to either duration dependence, i.e. falling exit rates with the length 
of the unemployment spell, or unemployment recurrence, i.e. a higher job loss rate in one's next job than if the person had not gone through an unemployment spell. While duration dependence is documented by the existing literature, we ..nd that unemployment recurrence is also present, although it does not appear to be a very strong phenomenon. This is somewhat surprising in the light of the presumption that a worker is very likely to exit unemployment with a temporary contract, and suggests that these contracts have not concentrated the burden of mobility on a subset of people who would move between employment and unemployment ${ }^{4}$ (abstracting from the age dimension). Otherwise, one would probably have observed stronger unemployment recurrence.

F inally, there is evidence that the unemployed are twice less successful at ..nding jobs than employed job seekers. We interpret this as employers giving preference to employed applicants in their hirings decisions. According to K ugler and Saint-Paul (2000), this discrimination against the unemployed is due to employment protection legislation; it explains why job-to-job moves account for a much greater fraction of worker reallocation in Europe compared to the U.S.; it also suggests that a reduction in employment protection legislation would reduce employers' discrimination against the unemployed.

\section{The composition of the labour force.}

Following Cohen et al., we start by looking at the compositioon of the labor force across cells de..ned by age, sex, and education. Here we report the composition of the labor force split under three educational categories, which correspond to primary, secondary, and tertiary education, respectively. When we will deal with Spain alone, we will further distinguish between vocational

\footnotetext{
${ }^{4} \mathrm{~T}$ his is somewhat at variance with the conclusion reached by Alba-Ramirez (1997), although it is a clear case of a bottle being half-empty and half-full.
} 
training and general training, as far as secondary education is concerned. But for the sake of comparison with France and the U.S. it is better to use three categories.

Cohen et al. could explain a large fraction of the unemployment dixerential between France and the US by a composition exect. For example, for the core age group of males, all of the unemployment dixerential was explained by the fact that on average French workers are less educated. The same was true for women provided one looked at non-employment rates rather than employment rates. In Spain, where the unemployment rate is almost twice as high as in France, there is no way one can explain high unemployment by a simple composition exect. However, the composition exect is present, since the composition of the workforce is dixerent.

\begin{tabular}{lllll}
\hline \hline & & France & USA & Spain \\
\hline \multirow{2}{*}{ AII } & E1 & 35.9 & 16.7 & $45: 05$ \\
& E2 & 48.1 & 60.1 & 45 \\
& E3 & 15.7 & 23 & $9: 925$ \\
& & & & \\
$16-24$ & E1 & 32.5 & 29.2 & $11: 1$ \\
& E2 & 60.0 & 63.1 & $83: 0$ \\
& E3 & 7.4 & 7.7 & 6.1 \\
& & & & \\
$25-49$ & E1 & 30.6 & 11.6 & $40: 55$ \\
& E2 & 51.0 & 60.6 & $45: 2$ \\
& E3 & 18.5 & 27.7 & $14: 1$ \\
& & & & \\
$50-64$ & E1 & 58.0 & 22.8 & $83: 5$ \\
& E3 & 10.6 & 55.4 & $11: 7$ \\
& 21.7 & $5: 2$ \\
\hline \hline \multicolumn{7}{l}{ Table 1: composition of the workforce. }
\end{tabular}

As can be seen in Table 1, Spain turns out to be the least educated of the three, as one would hazve expected. However, for the most recent generation, 
Spain seems to be quite ahead of France and the U.S. in terms of lifting the whole population above level E1 (primary school only). This represents a truly amazing exort given that for the older generation more than $80 \%$ of the population did not exceed that level! We expect this improvement in the quality of the Spanish workforce to contribute to a reduction in Spanish unemployment in the future.

\section{Unemployment Rates}

We now turn to a comparison of unemployment rates across groups and countries. Table 2 reports unemployment rates by categories for males, and table 3 does the same for females.

\begin{tabular}{lllll}
\hline \hline & & France & USA & Spain \\
\hline & E1 & 27.8 & 17.4 & 44.2 \\
$16-24$ & E2 & 14.3 & 8.45 & 36 \\
& E3 & 8.0 & 3.3 & 52.7 \\
& & & & \\
& E1 & 10.8 & 10.8 & 18.7 \\
$25-49$ & E2 & 5.25 & 5.03 & 15.4 \\
& E3 & 2.6 & 2.4 & 11.1 \\
& & & & \\
51 & 11.1 & 6.6 & 13.5 \\
$50-64$ & E2 & 6 & 3.2 & 9.1 \\
& E3 & 4.0 & 1.9 & 2.6 \\
\hline \hline
\end{tabular}

Table 2: male unemployment rates by categories. ${ }^{5}$

\footnotetext{
${ }^{5}$ Source: Cohen et al. (1997) for France and the US, Our computations from EPA for Spain. The years were1989 for USA, 1990 for France and 1994 for Spain, which have similar growth rates of about $2.5 \%$.
} 


\begin{tabular}{lllll}
\hline \hline & & France & USA & Spain \\
\hline & E1 & 39.6 & 16.4 & 53 \\
$16-24$ & E2 & 23.1 & 8.4 & 48.8 \\
& E3 & 7.5 & 2.4 & 60.5 \\
& & & & \\
& E1 & 16.7 & 10.4 & 30.8 \\
$25-49$ & E2 & 10 & 4.4 & 32.8 \\
& E3 & 4.6 & 2.2 & 20.4 \\
& & & & \\
E1 & 14.3 & 4.0 & 14.9 \\
$50-64$ & E2 & 10.1 & 2.64 & 17.4 \\
& E3 & 2.9 & 1.1 & 2.2 \\
\hline \hline
\end{tabular}

The similarities between France and the US regarding the core age group obviously breaks down when Spain enters into the picture, as Spain has an unemployment rate about twice as high as France. Nevertheless the property that the young are the most harmed is true of Spain as of France. But the composition exect certainly explains a lower fraction of Spanish unemployment than when one compares France and the US. Nevertheless, the unemployment dixerential between the most and least educated in the core age group is $7 \%$ for men and $10 \%$ for women. The rapid improvement in the quality of the Spanish workforce documented in the previous section will therefore reduce unemployment by a substantial amount. Although the net exect crucially depends on elasticities of substitution across groups as well as the curvature of the wage formation schedule, a reasonable estimate is probably in the range of 2 to 5 percentage points.

It is also true that women have a higher unemployment rate than men in both France and Spain, but not in the US. A variety of hypothesis can be formulated to explain such a dixerence-from pure discrimation to statistical discrimination, to greater incentives for women to register as unemployed rather than as out of the labor force. The latter explanation may be especially 
relevant given that Cohen et al. have found quite similar employment rates between French and American women.

The next table reports the "age gradient" of unemployment - i.e., the relative unemployment rate of the young vs. the middle aged - for each educational group. This gradient is remarkably constant across categories when computed as a ratio and is highest in France and lowest in the US, with Spain in the middle.

\begin{tabular}{ll|l|l|lll}
\hline \hline \multicolumn{4}{c|}{ A bsolute dixerence } & \multicolumn{3}{l}{ Ratio } \\
\multicolumn{1}{l|}{} & F & USA & Sp & F & USA & Sp \\
\hline & & & & & & \\
E1 & 17 & 6.6 & 25.5 & 2.57 & 1.6 & 2.36 \\
E2 & 9.05 & 3.42 & 20.6 & 2.72 & 1.68 & 2.33 \\
E3 & 4.7 & 0.9 & 41.6 & 2.42 & 1.4 & 4.74 \\
\hline \hline
\end{tabular}

Next we perform a similar exercise by looking at the relative unemployment rate of the least educated. Our benchmark is not the most educated but the next category, as some speci..c phenomena might be going on for the best educated.

\begin{tabular}{ll|l|l|lll}
\hline \hline \multicolumn{6}{c|}{ A bsolute dix. } & \multicolumn{3}{l}{ ratio } \\
& $\mathrm{F}$ & USA & Sp & $\mathrm{F}$ & USA & Sp \\
\hline & & & & & & \\
$16-24$ & 13.5 & 8.95 & 8.2 & 1.94 & 2.06 & 1.23 \\
$25-49$ & 5.55 & 5.77 & 3.3 & 2.05 & 2.15 & 1.21 \\
$50-64$ & 5.1 & 3.4 & 4.4 & 1.85 & 2.06 & 1.48 \\
\hline \multicolumn{7}{l}{ table 5: the skill gradient. }
\end{tabular}

The ratios are somewhat more stable than when one looks at dixerentials according to age, but the results are striking. The ratio between unskilled 
and skilled unemployment is about 2 in both France and the US, and just 1.21.3 for Spain. Thus, while in Europe it is the young that are hit the hardest by unemployment relative to other groups, in the US it is the least educated. This may be ascribed to two factors. First, technology is less biased in favor of the skilled in Europe, and being unskilled is less of a handicap when there are more unskilled people around. Second, the two-tier style of labor market reforms in Europe has concentrated the burden of łexibility on new entrants, especially the young but also women. This is con..rmed by the next tables that look at labor market ‡ows.

\section{Flows}

We now compare workers $\ddagger$ ows across the three countries. Cohen et al. report monthly ‡ows while our data only allow us to catch quarterly ‡ows. In order to make the ..gures comparable we report the monthly ‡ows consistent with our data under the hypothesis that hirings and separations follow a Poisson process. This is done by computing the "cubic root" of our estimated 3-state transition matrix. That is, if we call the latter $P$; $Q$ such that $Q^{3}=P: 6$

We ..rst start by comparing hiring rates, i.e. transitions from unemployment to employment.

\begin{tabular}{llll}
\hline \hline & France & Spain & USA \\
\hline Males & 5.97 & 7.24 & 23.8 \\
Females & 4.77 & 4.06 & 29.4 \\
\hline \hline \multicolumn{7}{l}{ Table 6: } & A ggregate job ..nding rates
\end{tabular}

\footnotetext{
${ }^{6}$ In practice this is done by ..rst diagonalizing $\mathrm{P}: \mathrm{MF} \mathrm{M}^{\mathrm{i}}{ }^{1}$; where $\mathrm{F}$ is diagonal, and

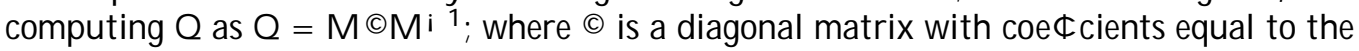
cubic roots of the coed cients of $F$ :
} 
The aggregate job ..nding rates tell us that Spain is more comparable to France than to the US. The labor market for men is more active than its French counterpart, while the reverse holds for women. In both countries men's job ..nding rate is higher than women's, while the pattern is inverted in the US. A variety of explanations can be put forward for that pattern (see below).

We then compare more deeply by disaggregating across groups.

\begin{tabular}{lllll}
\hline \hline & & France & USA & Spain \\
\hline & E1 & 8.3 & 26.5 & 7.8 \\
$16-24$ & E2 & 10.85 & 31.1 & 8.3 \\
& E3 & 9.7 & 40.0 & 4.9 \\
& & & & \\
& E1 & 5.2 & 30.0 & 8.0 \\
$25-49$ & E2 & 7.5 & 30.7 & 7.05 \\
& E3 & 8.15 & 22.4 & 5.1 \\
& & & \\
& E1 & 1.0 & 36.7 & 5.6 \\
$50-64$ & E2 & 1.4 & 28.5 & 3.4 \\
& E3 & 3.0 & 14.8 & 6.5 \\
\hline \hline \multicolumn{7}{l}{ Table 7: M onthly hiring rates, males }
\end{tabular}

A few remarkable features should be noted.

First, monthly hiring rates in Spain are similar in magnitude to their French counter-part that is, far below the US number.

Second, while for the core age group job ..nding rates are roughly increasing with education in France, they are declining in both Spain and the US. This may result from the fact that people are either more choosy or more specialized. On the other hand, the increasing pattern found in France may be the result of a "ranking" "overquali..cation" exect where the most skilled are preferred over the least skilled for any given job. This exect dominates in France, while the former exects dominate in Spain and the US. 
Third, in all three countries there is no evidence that the young have any more diф culty to ..nd a job than older workers, a point already commented in the Cohen et al. paper. This con.rms the above made point that the young's greater unemployment rate is explained by the fact that they bear the burden of $\ddagger$ exibility rather than any reluctance of employers to hire them, as would be suggested by theories blaming youth unemployment on the minimum wage.

Fourth, older workers are at a slight disadvantage in Spain and the U.S., while the French data suggest they are almost excluded from the workforce, with hiring rates as low as $1 \%$ for the least educated. This is consistent with the very large wage loss found for these workers by Cohen et al. for France and Rosolia and Saint-Paul for Spain. The interesting question is why is France so dixerent in terms of the treatment of 50-64 year old workers. One possible explanation is the prevalence of early retirement schemes and of other labour market policies that exclude the "old" to "make room for the young", based on the widespread fallacy that total employment is ..xed.

The next table reports female hiring rates.

\begin{tabular}{lllll}
\hline \hline & & France & USA & Spain \\
\hline & E1 & 7.0 & 24.2 & 5.9 \\
$16-24$ & E2 & 10 & 29.4 & 4.96 \\
& E3 & 21.3 & 50.0 & 6.4 \\
& & & \\
& E1 & 4.2 & 22.1 & 3.5 \\
$25-49$ & E2 & 6.82 & 25.1 & 2.95 \\
& E3 & 8.4 & 27.2 & 1.0 \\
& & & \\
& E1 & 0.7 & 16.2 & 2.8 \\
$50-64$ & E2 & 2.05 & 25.05 & 2.1 \\
& E3 & 1.5 & \multicolumn{3}{c}{0.0} \\
\hline \hline
\end{tabular}

The Spanish data suggest that Spanish society is more "traditional" than 
either French or US society.

For the 16-24 year old the job ..nding rates are comparable between men and women in all three countries, indeed higher for women in the most educated groups (as much as twice higher in France), perhaps because men elect more specialized occupations. Yet even for the young the Spanish ‡ows are typically lower for women than for men (except for the most educated group), whereas they are basically the same for men and women in France and the US, and higher for women in the most educated groups.

In the core age group hiring rates are quite similar across sexes in both France and the US, while they are dramatically lower for women in Spain. This may be due to the fact that they do not search as intensively as men because they are more likely to be secondary earners (and also because the primary earner is less likely to be unemployed, as many Spanish study show a very low unemployment rate for household heads); or to the fact that employers prefer male applicants (discrimination). The two explanations are not mutually exclusive.

It would be interesting to know whether the dixerence of hiring rates between young and middle aged-women is a cohort exect or an age exect. Do young women ..nd job more quickly in Spain than older ones because "times are changing" or because women's attachement to the workforce goes down after child-bearing?

We now turn to the analysis of job loss. The ..rst table shows aggregate rates and the next one decomposes across groups. It is not clear in the Cohen et al. paper whether job loss represents transitions from employment to unemployment or from employment to either unemployment or out of the labor force. Furthermore the concepts might not be that easy to compare across countries. For this reason, for Spain we report both a lower bound which is the employment to unemployment $\ddagger$ ow, and an upper bound which is the out $\ddagger$ ow from employment. 


\begin{tabular}{|c|c|c|c|c|c|}
\hline & & France & $\overline{\mathrm{USA}}$ & \multicolumn{2}{|l|}{ Spain } \\
\hline \multirow{3}{*}{\multicolumn{2}{|c|}{$\begin{array}{l}\text { Males } \\
\text { Females }\end{array}$}} & & & Lower Bound & Upper B ound \\
\hline & & 0.5 & 2.84 & 1.47 & 2.07 \\
\hline & & 0.83 & 3.18 & 1.79 & 2.93 \\
\hline \multicolumn{6}{|c|}{ "Table 9: A ggregate job loss. } \\
\hline & \multirow{2}{*}{\multicolumn{2}{|c|}{ France }} & e USA & \multicolumn{2}{|l|}{ Spain } \\
\hline & & & & Lower Bound & Upper B ound \\
\hline \multirow{3}{*}{$16-24$} & E1 & 3.2 & 10.8 & 5 & 6.1 \\
\hline & E2 & 2.6 & 6.6 & 3.6 & 5.5 \\
\hline & E3 & 1.2 & 1.3 & 3 & 10.5 \\
\hline \multirow{3}{*}{$25-49$} & E1 & 0.69 & 5.4 & 1.8 & 2.1 \\
\hline & E2 & 0.48 & 2.05 & 1.33 & 1.53 \\
\hline & E3 & 0.38 & 1.3 & 0.5 & 0.7 \\
\hline \multirow{3}{*}{$50-64$} & E1 & 1.1 & 3.6 & 0.6 & 1.6 \\
\hline & E2 & 0.7 & 2.6 & 0.32 & 1.0 \\
\hline & E3 & 0.52 & 1.55 & 0.2 & 0.6 \\
\hline
\end{tabular}

Table 10: Male job loss rate.

A few very interesting patterns emerge from this table.

First, Spain, just like France, has much smaller job loss rates than the U.S. This is clearly due to the more stringent job security legislation in Europe compared to the US.

Second, however, job loss is much more likely to occur in Spain than in France. In other words, the higher Spanish unemployment compared to France seems much more due to high job loss than to low job ..nding. An obvious suspect for explaining that is the wide use of temporary contracts by Spanish ..rms. It looks as if they increased job destruction but not job creation! However, if it was the only story it would not explain why unemployment was so high prior to the liberalization of temporary contracts. One possible explanation, is that then job creation was much lower, and that 
temporary contracts increased job creation and job destruction by similar proportions, leaving the overall unemployment rate essentially unchanged. But then, that would imply that absent temporary contracts, job ...nding rates would be much lower than in France, a feature dic cult to interpret. More could be obtained by looking at ‡ow prior to the reform, i.e. prior to 1984 , but this runs into the diф culty that the Labour force survey has a panel structure only since 1986, and the panel dimension is essential in order to compute ‡ows.

Third, overall Spain reproduces the features of the other economies, namely a job loss rate that is falling with age and education (while the job ..nding rate is less sensitive to education). Note however that in both France and Spain, the job loss rate for young workers is 3 to 6 times greater than for the middle-aged, while in the U.S. it is 1 to 3 times greater. Thus in Europe the young's jobs are much more precarious relative to the middleaged than in the U.S., con..rming our point that they bear the burden of fexibility.

F inally, women's job loss rate is higher than men's in all three countries, with the relative dixerence being perhaps highest in France.

\section{Non stationarity in hazard rates}

Our data allow us to compute transition rates both on a quarterly basis and on a yearly basis. One can therefore compute the dixerence between yearly transition rates and their predicted values under the assumption that transition probabilities per unit of time are constant - i.e. under the assumption that the underlying process is Markov.

Discrepancies between the two may stem from several sources. Consider for example the exit from unemployment into employment ("job ..nding"). If we ..nd that job ..nding over a horizon of one year is lower than predicted by the Markov model, this may be an indication that exit rates from unem- 
ployment are falling with the duration of the unemployment spell (negative duration dependence). But, it may also mean that the jobs found by unemployed people are more precarious - i.e., have a higher death rate - than the average of the economy, so that a greater fraction of them will be back to unemployment after one year. We call that phenomenon unemployment recurrence.

For any two states $A$ and $B$; we de..ne as the path dependence index for the fow from $A$ to $B$ the following quantity:

$$
P D I_{A B}=1 i \frac{Y_{A B}}{Y_{A B}^{M a r k o v}} ;
$$

where $Y_{A B}$ is the transition rate from $A$ to $B$ computed on a yearly basis, and $Y_{A B}^{M}$ arkov is its predicted value on the basis of the quarterly transition matrix raised at the fourth power.

A positive index implies that $Y_{A B}<Y_{A B}^{\text {Markov: }}$ T his means that conditional on what happens meanwhile, being in unemployment at $t$ typically increases the probability of being unemployed one year from $t$ : Path dependence reł ects both the contribution of duration dependence and unemployment recurrence. These two phenomena may in turn be either "genuine" - i.e., a given person has lower chances to ..nd a job if he or she has been unemployed longer - or refect unobserved heterogeneity - i.e., long-term unemployed have a lower quality on average and therefore a lower exit rate.

\subsection{Path dependence in Spain}

We ..rst compute our path dependence index for the various categories of the Spanish economy. We now use a decomposition into 4 educational groups, splitting group E 2 into general and vocational training.

Tables 11 and 12 summarize the path dependence index for men, for job loss and job ..nding respectively. Tables 13 and 14 give the same information for women; these ..gures are very unreliable for women older than 50 because 
there are only few people in each cell; we therefore do not report the results for that group.

The stylized facts are the following:

1. Transitions from employment to unemployment exhibit positive path dependence both for men and women. This means that job loss falls as tenure increases; or that people who just lost their jobs are back into the employment pool more quickly than the average of the unemployed, perhaps because of negative duration dependence of exit rates from unemployment.

2. Exits from unemployment also exhibit path dependence for both men and women.

3. For both men and women, path dependence is typically increasing with education as far as job ..nding is concerned. This suggests that accumulation of speci..c human capital on the job is more important for workers with higher education, implying a steeper negative exect of tenure on the job loss rate. The case of young women is particularly salient. For this group, job loss is increasing with education on a quarterly basis but falling on a yearly basis.

4. For men, path dependence in job ..nding rates does not depend on education, except for the young where it is clearly decreasing with education. This suggests that unemployment recurrence and/ or negative duration dependence is more pronounced at low education levels, for the young, while for older workers it seems to be evenly distributed across educational levels. For women, path dependence in job ..nding rates decreases with education for both the young and the middle-aged. 


\begin{tabular}{|c|c|c|c|c|}
\hline \multicolumn{2}{|l|}{ Category } & Y early in $\ddagger$ ow & 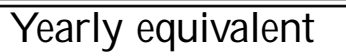 & $\overline{\text { P.D.I. }}$ \\
\hline \multirow[t]{4}{*}{ 16-24 years } & E1 & 17.8 & 28.4 & 0.37 \\
\hline & E2.1 & 11.3 & 17.7 & 0.36 \\
\hline & E2.2 & 11.7 & 18.4 & 0.36 \\
\hline & E3 & 10.8 & 18.5 & 0.41 \\
\hline \multirow[t]{4}{*}{$25-49$ years } & E1 & 6.6 & 12.1 & 0.45 \\
\hline & E2.1 & 4.9 & 10.3 & 0.52 \\
\hline & E2.2 & 3.7 & 8.7 & 0.57 \\
\hline & E3 & 1.9 & 4.6 & 0.59 \\
\hline \multirow[t]{4}{*}{ 50-64 years } & E1 & 3.4 & 4.4 & 0.22 \\
\hline & E2.1 & 1.7 & 3.1 & 0.45 \\
\hline & E2.2 & 3.1 & 2.9 & -0.06 \\
\hline & E3 & 0.8 & 2.1 & 0.61 \\
\hline \multicolumn{5}{|c|}{ Table 11: Path dependence in male job loss rate } \\
\hline \multicolumn{2}{|c|}{ Category } & P Yearly out $\ddagger$ ow & "Yearly equivalent & $\overline{P \text { P.D.I. }}$ \\
\hline \multirow[t]{4}{*}{ 16-24 years } & E1 & 29.5 & 42.8 & 0.31 \\
\hline & E2.1 & 32.9 & 39.5 & 0.17 \\
\hline & E2.2 & 32.6 & 40.4 & 0.19 \\
\hline & E3 & 20.8 & 21.2 & 0.02 \\
\hline \multirow[t]{4}{*}{$25-49$ years } & E1 & 35.4 & 54.9 & 0.35 \\
\hline & E2.1 & 37 & 52.3 & 0.29 \\
\hline & E2.2 & 35.4 & 54.6 & 0.35 \\
\hline & E3 & 27.3 & 42.4 & 0.36 \\
\hline \multirow[t]{4}{*}{$50-64$ years } & E1 & 19.2 & 37.9 & 0.49 \\
\hline & E2.1 & 17.9 & 24.6 & 0.27 \\
\hline & E2.2 & 22.2 & 41.7 & 0.46 \\
\hline & E3 & 25 & 53.5 & 0.53 \\
\hline
\end{tabular}

Table 12: Path dependence in job ..nding rates; men. 


\begin{tabular}{lllll}
\hline \hline Category & & Yearly in¥ow & Y early equivalent & P.D.I. \\
\hline 16-24 years & E1 & 21.2 & 24.1 & 0.12 \\
& E2.1 & 14.9 & 22.2 & 0.32 \\
& E2.2 & 14.1 & 25.1 & 0.43 \\
& E3 & 13.1 & 40.1 & 0.67 \\
25-49 years & E1 & 5.9 & 12.1 & \\
& E2.1 & 5.8 & 11.8 & 0.51 \\
& E2.2 & 5.8 & 15.5 & 0.51 \\
& E3 & 3.9 & 8.3 & 0.62 \\
\hline \hline
\end{tabular}

Table 13: Path dependence in female job loss rate

\begin{tabular}{lllll}
\hline \hline Category & & Yearly out $\ddagger$ ow & Yearly equivalent & P.D.I. \\
\hline 16-24 years & E1 & 19.2 & 34.8 & 0.44 \\
& E2.1 & 22.1 & 25.3 & 0.126 \\
& E2.2 & 23.7 & 27.7 & 0.144 \\
& E3 & 28.8 & 27.5 & -0.04 \\
25-49 years & E1 & 15.9 & & \\
& E2.1 & 14.1 & 24.3 & 0.34 \\
& E2.2 & 14.1 & 24.2 & 0.41 \\
& E3 & 24.6 & 29.8 & 0.33 \\
\hline \hline
\end{tabular}

Table 14: Path dependence in job ..nding rates; women.

In order to get a grasp at the phenomenon of unemployment recurrence, i.e. to disentangle it from duration dependence as a source of path dependence, we have estimated a probit regression explaining the probability of losing one's job as a function of the worker's characteristics. ${ }^{7}$ This is obviously a gross way of testing for recurrence, as ideally one would prefer to condition over the whole labor market history of the worker. However, because of the limited panel dimension of the Spanish Labour Force Survey, we restrict ourselves to tenure in the current job. The results con..rm a declining

\footnotetext{
${ }^{7}$ In order to increase the quality of the econometric results, the estimation was carried for years 92,94 and 96 pooled.
} 
dependence of job loss with respect to tenure. The following table illustrates the exect. The exect is relatively modest.

\begin{tabular}{llll}
\hline \hline Category & & Tenure $=0$ & Tenure $=2$ years \\
\hline 16-24 years & E1 & 16.4 & 14.4 \\
& E2.1 & 12.9 & 11.2 \\
& E2.2 & 11.7 & 10.1 \\
& E3 & 8.6 & 7.3 \\
25-49 years & E1 1 & 10.1 & 8.7 \\
& E2.1 & 7.7 & 6.5 \\
& E2.2 & 6.8 & 5.7 \\
& E3 & 4.8 & 4.0 \\
& & \\
$50-64$ years & E1 & 7.7 & 6.5 \\
& E2.1 & 5.7 & 4.7 \\
& E2.2 & 5.0 & 4.2 \\
& E3 & 3.5 & 2.8 \\
\hline \hline
\end{tabular}

Table 15: Quarterly job loss rate by tenure (men).

Therefore, while there is evidence of unemployment recurrence in Spain, it does not seem to be a very important phenomenon quantitatively, even though fresh hires are more likely to hold a temporary contract. The bulk of path dependence is explained by duration dependence, a phenomenon widely documented elsewhere (see e.g. Bover and Gómez (1999)). That is, while the long-term unemployed have trouble ..nding jobs, unemployment spells do not seem to result in a state of "precariuousness", with frequent spells between employment and unemployment. 


\section{Discrimination between employed and un- employed job seekers}

A nother important aspect of the labor market that we have neglected up to now is the pattern of job-to-job mobility. In a rigid labor market we expect increased job to job mobility to partly make up for reduced mobility from unemployment to employment, because workers who want to change jobs are reluctant to go through a period of unemployment and prefer to search on the job instead. Furthermore, as Kugler and Saint-Paul (1999) argue, labor market rigidities induce employers to prefer hiring employed job seekers over unemployed ones because employment protection regulation makes them more sensitive to unobserved workers quality - i.e., hiring an employed job seeker provides and insurance against bad worker quality. The basic intuition is that low ability workers are more likely to lose their jobs than high ability ones, so that the pool of unemployed workers is of lower quality than the pool of employed job seekers. A bsent employment protection legislation hiring someone is a one way bet as one can always get rid of the worker if he or she turned out to be of low quality. The more stringent that legislation, the more employers are reluctant to take the risk of hiring an unemployed worker, and the lower the exit rate of the unemployed relative to the employed.

To what extent is that phenomenon present in the Spanish labor market? To measure it we just compute the ratio between the quarterly exit rate from unemployment and the job ..nding rate of employed job seekers, as de..ned by those employed workers who state that they are looking for another job in the EPA questionnaire. We call this ratio the Unemployment Discrimiation Indicator. The lower that indicator, the greater the discrimination against the unemployed. The following table reports the results, where again we only use three employment categories. 


\begin{tabular}{rrll}
\hline \hline \multicolumn{2}{l}{ Category } & U.D.I (Men) & U.D.I. (Women) \\
\hline $16-24$ & E1 & 0.56 & 0.51 \\
E2 & 0.62 & 0.43 \\
E3 & 0.40 & 0.5
\end{tabular}

$\begin{array}{rrrr}25-49 & \text { E1 } & 0.57 & 0.32 \\ \text { E2 } & 0.54 & 0.26 \\ \text { E3 } & 0.44 & 0.36\end{array}$

$\begin{array}{llll}50-65 & \text { E } 1 & 0.38 & 0.39\end{array}$

E2 $0.17 \quad 0.14$

Table 16: Unemployment Discrimination Indicator

The table clearly con..rms that the unemployed have a lower probability to ..nd a job than employed job seekers, with a ratio of about 0.5 . A nother interesting aspect is that at least for men, discrimination against the unemployed increases with the worker's education. At face value, this may sound paradoxical because one might believe rigidities to be more binding for less educated workers. We suspect that our results indicate that unobserved ability is more of an issue at higher education levels. Interestingly, this does not seem to be so much true for women.

To further deepen our understanding of this phenomenon, we distinguish according to the type of contract of the new job. It is well known that the Spanish labor market has temporary and permanent workers, with the majority of new hires being on temporary contracts. A priori one might expect employers to be more reluctant to give a permament contract to an unemployed job seeker, since the employer is more likely to regret such a decision due to the expected lower quality of the pool of applicants. hence, we expect the proportion of temporary contracts in a new job to be higher for unemployed job seekers than employed job seekers, or, equivalently, that the unemployment discrimination indicator is lower in permanent contracts 
than in temporary ones.

The following table tests that hypothesis by comparing the share of temporary contracts in new jobs for both employed and unemployed applicants.

\begin{tabular}{rrll}
\hline \hline \multicolumn{2}{l}{ Category } & Unemployed & E mployed \\
\hline 16-24 & E1 & 91.11 & 97.0 \\
& E2 & 96.05 & 94.5 \\
& E3 & 86.9 & 94.6
\end{tabular}

$\begin{array}{llll}25-49 & \text { E1 } & 91.6 & 93.8 \\ & \text { E2 } & 89.1 & 93.3 \\ \text { E3 } & 79.5 & 84.7\end{array}$

\begin{tabular}{rrrr}
$50-65$ & E1 & 91.4 & 93.1 \\
& E2 & 87.5 & 88.5 \\
E3 & 66.7 & 71.4 \\
\hline
\end{tabular}

Table 17: Share of temporary contracts in new jobs according to job seeker characteristics; men.

\begin{tabular}{rrll}
\hline \hline Category & Unemployed & Employed \\
\hline 16-24 & E1 & 86.7 & 92.7 \\
& E2 & 90.9 & 93.7 \\
& E3 & 93.6 & 95.1
\end{tabular}

\begin{tabular}{llll} 
25-49 & E1 & 86.1 & 92.7 \\
& E2 & 89.6 & 92.0 \\
& E3 & 90.1 & 88.7 \\
$50-65$ & E1 & 81.6 & 87.3 \\
& E2 & 55.6 & 80.9 \\
& E3 75.0 & 80 \\
\hline Table 18: Share of temporary contracts in new jobs according to job \\
ker characteristics; women.
\end{tabular}


The table con..rms the earlier ..ndings of the literature, namely that temporary contracts account for the vast majority of new hires. More interestingly, with the exception of older women for whom there are too few observations to draw any con..dent conclusion, the results go strikingly against our prior. The fraction of new jobs that are temporary is systematically higher for employed job seekers than for unemployed job seekers.

This may indicate that discrimination by the employer is not an important phenomenon, and that the lower job ..nding probability of the unemployed job seekers may be due to other factors, such as the disincentive exects of unemployment bene..ts. A nother interpretation, however, is that workers dixer across their (unobservable) preference for job duration, so that those who prefer long jobs will turn down oxers more often and will represent a greater fraction of the unemployed. Because of this composition exect the unemployed are more likely to end up with a permanent contract than employed job seekers. Hence, in order to capture the pure exect of discrimination, it would be necessary to come up with a proxy for the unobservable taste for secure jobs. 


\section{R eferences}

Alba-R amirez, A lfonso (1997) "How temporary is temporary employment in Spain?", working paper 97-14, Universidad Carlos III, Madrid

Bentolila, S. and J. Dolado (1994) "Labor łexibility and wages: lessons from Spain", Economic P olicy

Bentolila, S. and G. Saint-Paul (1992) "The macroeconomic impact of ‡exible labor contracts, with an application to Spain", European Economic Review

Bertola, G. and A. Ichino (1996) "Crossing the river" E conomic Policy

Blanchard, O., J . J imeno, J . Andrés, C. Bean, E. Malinvaud, A. Revenga, G. Saint-Paul, D. Snower, R. Solow, D. Taguas, L. Toharia (1995), Spanish Unemployment: Is There a Solution?, CEPR

Bover, O. and R. Gómez (1999), "Nuevos resultados sobre la duración del desempleo: el paro de larga duración y la salida a un empleo ..jo" Banco de España, Servicio de Estudios, Documento de Trabajo no 99-03

Cohen, D., A. Lefranc and G. Saint-Paul, (1997) "French unemployment: a transatlantic perspective", E conomic Policy

Garcia Perez, J .I. (1997), "Las tasas de salida del empleo y el desempleo en España", Investigaciones E conomicas, 21 (1), 29-53

Garcia-Fontes, W. and H. Hopenhayn (1993), "Flexibilización y volatilidad del empleo" in R. Marimon, ed., La Economia Española: Una visión diferente.

J imeno, J . and L. Toharia (1991) "P roductivity and wage exects of temporary employment contracts", mimeo, FEDEA

K ugler, A. and G. Saint-Paul (2000) "Hiring and Firing Costs, A dverse Selection, and L ong-Term U nemployment", Working paper, U niversitat Pompeu Fabra

Segura, J., F. Duran, L. Toharia and S. Bentolila (1991), Analysis de la contratación temporal en España. Madrid: Ministerio de trabajo. 